\title{
Isolation of Cellulolytic Fungi and Utilization of Its Cellulolytic Activity for Microcrystalline Cellulose Preparation from Water Hyacinth (Eichhornia crassipes)
}

\author{
Mitayani Wahyu Murti, Monica Angeline Sudarsono, Herman Suryadi*
}

\section{Mitayani Wahyu Murti, Monica Angeline Sudar- sono, Herman Suryadi*}

\section{Laboratory of Microbiology and} Biotechnology, Faculty of Pharmacy, Universitas Indonesia, INDONESIA.

\section{Correspondence}

Dr. Herman Suryadi, M.S., Apt.

Laboratory of Microbiology and Biotechnology, Faculty of Pharmacy, University of Indonesia, Depok, INDONESIA.

Phone no : +62 812-1828-612

E-mail: hermans001@yahoo.com

History

- Submission Date: 23-01-2018;

- Review completed: 05-03-2018,

- Accepted Date: 25-08-2018

\section{DOI : 10.5530/pj.2018.6.183}

Article Available online

http://www.phcogj.com/v10/i6

\section{Copyright}

(C) 2018 Phcog.Net. This is an openaccess article distributed under the terms of the Creative Commons Attribution 4.0 International license.

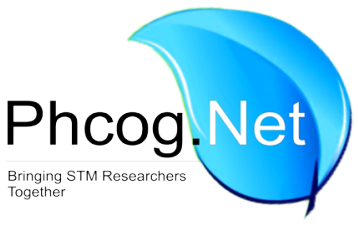

\begin{abstract}
Introduction: Microcrystalline cellulose is a cellulase derivative which usually used as a pharmaceutical excipient in the manufacturing of direct compression tablet. High concentration of cellulose is found in water hyacinth (about 60\%) therefore it might be used in the manufacturing of microcrystalline cellulose. This study was aimed to obtain the best cellulolytic fungi, the best optimal conditions of enzymatic hydrolysis and comparing microcrystalline cellulose characteristics obtained from water hyacinth with microcrystalline cellulose standard, Avicel $\mathrm{pH}$ 101. Method: This study began with isolation of cellulolytic fungi, and then enzymatic hydrolysis of $\alpha$-cellulose was done with cellulase enzymes extracted from cellulolytic fungi with various $\mathrm{pH}$, temperature, duration and enzyme concentration. Microcrystalline obtained was characterized by XRD (X-Ray Diffraction) and then the result was compared with Avicel $\mathrm{pH}$ 101. Results: The results showed the best cellulolytic isolate was isolate 2 and its optimal hydrolysis conditions at $\mathrm{pH} 5,30^{\circ} \mathrm{C}$, for $1 \mathrm{~h}$ with $5 \mathrm{~mL}(5 \% \mathrm{v} / \mathrm{v})$ enzyme. Based on the pattern of diffraction there was a similarity between microcrystalline cellulose of enzymatic hydrolysis result compared with Avicel $\mathrm{pH} 101$.
\end{abstract}

Key words: Cellulolytic fungi, Cellulase, Cellulose, Microcrystalline cellulose, Water hyacinth, Enzymatic hydrolysis.

\section{INTRODUCTION}

Indonesia is a country with abundant biodiversity. Those various species have various resources to be processed further to improve the welfare of the community. One of them is cellulase, which is the main structural component of green plant cell wall. The ubiquitous availability of cellulase from plants may be utilized and developed to produce useful and valuable products, including pharmaceutical products. One of the plants containing cellulase is water hyacinth (Eichhornia crassipes). ${ }^{1}$

Water hyacinth (Eichhornia crassipes) is a species of aquatic plants commonly grown on the surface of lakes and rivers. The growth of water hyacinth is very rapid due to their excellent adaptability in a variety of freshwater ecosystems, both crystal clear and waste water. ${ }^{2}$ The abundant and uncontrolled growth of hyacinths on water surfaces makes this plant often referred as one of the most problematic weeds in the world. The rapid growth of water hyacinth can reach $60 \mathrm{~kg} / \mathrm{m}^{2}$, this can lead to water bodies blockage that will adversely affect the environment, human health, and economic development. ${ }^{3}$ Therefore, this problem of this water hyacinth population need to be addressed.

Water hyacinth has been utilized by processing it as art paper, bioethanol, particle board, and membrane manufacturing. ${ }^{4}$ However, these utilizations are still not optimal. Thus, other uses are still needed to reduce the number of high water hyacinth populations. Regarding its composition, the biomass of water hyacinth contains $60 \%$ cellulase, $8 \%$ hemicellulose, and $17 \%$ lignin. ${ }^{1}$ This high cellulase content is interesting to be used for the production of microcrystalline cellulose.

Microcrystalline cellulose is an essential ingredient in the pharmaceutical, food, cosmetic, and other industrial preparations. Microcrystalline cellulose in pharmaceutical preparations is used for fillers in direct compression tablet. Microcrystalline cellulose in the pharmaceutical industry is usually obtained from wood pulp and cotton linters. Cotton is a high value-added plant and wood is obtained usually through deforestation. The need for environmentally friendly processes as well as reducing massive deforestation encourages the interest of utilizing other alternative sources of fiber-rich weeds. ${ }^{5}$

The most common method of producing microcrystalline cellulose is by using a chemical process called acid hydrolysis. Acid hydrolysis uses strong acids to remove amorphous parts of cellulose to produce particles consisting microcrystals. ${ }^{6}$ However, chemical 
hydrolysis will require high activation energy and the resulting waste is less environment-friendly. Thus, microcrystalline cellulose production is being developed using cellulose enzymes or enzymatic hydrolysis. ${ }^{7}$ There are several advantages of enzymatic hydrolysis. Those advantages are: the ability to be done at low temperature, no sugar degradation, and can give higher yield. ${ }^{8}$ This study developed the conversion of water hyacinth powder into microcrystalline cellulose by enzymatic hydrolysis method. The cellulose enzyme was obtained from selected fungi isolated from several sources: oil palm trunk, rotten logs, and the soil around landfills and water hyacinth was used as the source of cellulose.

\section{MATERIALS AND METHODS}

Water hyacinth was obtained from Badan Penelitian Tanaman Rempah dan Obat (Balitro), Bogor, Indonesia. Potential fungi sources were derived from oil palm trunks and rotten logs collected from University of Indonesia forest, and the soil around Ciliwung river landfills. Trichoderma reesei was used as a comparison strain. It was obtained from IPBCC (IPB Culture Collection), Bogor, Indonesia. Colonies of interest were isolated and sub-cultured to obtain pure cultures on potato sucrose agar which contained potato filtrate, sucrose, and technical grade agar. Stock cultures were maintained on potato dextrose agar (Difco) at $28^{\circ} \mathrm{C}$.

\section{Instruments and method}

Autoclave (Tomy), oven (WTB Binder), analytical balance (Acculab), waterbath shaker, hotplate stirrer (Corning), pH meter (Hanna), centrifugator (Kubota 6800), incubator (Memmert), microscope (Micromax), air shaking incubator (Heidolph Inkubator 1000) filter paper, ose, pipette volume and other glass wares commonly used in laboratories.

The instruments analysis used were UV-Vis spectrophotometer (Shimadzu UV-1601) and X-ray diffractogram (Bruker D8 Advance ECO).

\section{Chemicals}

Sucrose, glucose (Merck), acetic acid glacial (Merck), Avicel pH 101 (aicma), CMC, sodium hydroxide (Bratachem), sodium hypochlorite (Bratachem), sodium sulfite (Bratachem), nitric acid (Bratachem), sodium nitrite (Bratachem), ethanol (Merck), acetate buffer, urea (Merck), tween 80 (Merck), ammonium sulphate (Merck), potassium dihydrogen phosphate (Merck), sodium potassium tartrate (Merck), sodium hydroxide (Merck), magnesium sulfate heptahydrate (Merck), iron (II) sulfate heptahydrate (Merck), yeast extract (Difco), dinitro salicylic acid (Sigma), distilled water, double distilled water, and lactophenol blue solution (Merck).

\section{Isolation and Screening of Cellulose Producing Fungi}

Isolation cellulose producing fungi from oil palm trunk, rotten logs, and soil

Oil palm trunk, rotten logs, and soil up to $100 \mathrm{mg}$ were crushed and rinsed with sterile distilled water. Serially diluted suspensions (up to $10^{-9}$ ) were spread on the surface of potato sucrose agar and incubated for 7 days at $28^{\circ} \mathrm{C}$. Colonies were isolated and sub-cultured to obtain pure cultures and stock cultures were maintained on potato dextrose agar at $4^{\circ} \mathrm{C}$. The isolated fungi were carefully identified by morphological characteristics such as the growth pattern studies and color of the colony. The isolates were screened for cellulase production.

\section{Cellulase preparation}

Spore suspensions of fungal isolates were harvested with double distilled water for cellulase preparation. Ten milliliters of the spore suspension in $0.1 \%$ tween 80 was inoculated into a mineral nutrient solution that contained $200 \mathrm{mg}$ yeast extract, $750 \mathrm{mg}$ urea, $280 \mathrm{mg}\left(\mathrm{NH}_{4}\right)_{2} \mathrm{SO}_{4}, 400 \mathrm{mg}$ $\mathrm{KH}_{2} \mathrm{PO}_{4}, 150 \mathrm{mg} \mathrm{MgSO} \cdot 7 \mathrm{H}_{2} \mathrm{O}, 1 \mathrm{mg} \mathrm{FeSO} .7 \mathrm{H}_{2} \mathrm{O}, 5 \mathrm{~mL} \mathrm{CMC} 1 \%$ and $0,1 \mathrm{M}$ acetate buffer $\mathrm{pH} 5$ to make up $200 \mathrm{~mL}$. The solution was stirred at $150 \mathrm{rpm}$ for $120 \mathrm{~min}$ at room temperature. Thirty milliliters of the solution was aliquoted and centrifuged at $966 \mathrm{~g}$ for $10 \mathrm{~min}$ at $4^{\circ} \mathrm{C}$. The supernatant was collected and used for screening of cellulase activity. ${ }^{9}$

Screening of cellulase activity was done using the cellulose degradation test method. ${ }^{9}$ Five microliters of the crude enzyme extract from fungal isolates was injected to the paper disc using a micropipette. The disc was transferred on to a petri dish containing carboxy methyl cellulose (CMC), $\mathrm{NaNO}_{3}, \mathrm{KH}_{2} \mathrm{PO}_{4}, \mathrm{KCl}, \mathrm{MgSO}_{4} .7 \mathrm{H}_{2} \mathrm{O}$, yeast extract, glucose, technical colored agar. The petri dish was then incubated at room temperature for 7 days. As a control, another petri dish was inoculated with Trichoderma reesei. ${ }^{10}$ The isolates showing cellulolytic activity were seen from the formation of clear zones around the fungi colonies.

\section{Preparation of calibration curve standard glucose}

The DNS method ${ }^{11}$ was used to measure the reducing sugar concentration. A standard glucose calibration curve was developed at the concentration of $80 \mathrm{ppm}, 90 \mathrm{ppm}, 100 \mathrm{ppm}, 110 \mathrm{ppm}, 130 \mathrm{ppm}$ and $140 \mathrm{ppm}$. The standard solution gave absorbance ranged between $0.2-0.8$. The calibrators were then mixed with DNS $1 \%$ in 1:1 ratio. The mixture was heated in the water bath at $100^{\circ} \mathrm{C}$ for $10 \mathrm{~min}$ and allowed to cool to room temperature. Absorbance was again measured at $520 \mathrm{~nm} .{ }^{12}$

\section{Screening of cellulose activity based on DNS method}

A spore suspension of fungal isolates were inoculated into the mineral nutrient solution and incubated in an incubator shaker for $72 \mathrm{~h}$ at $50^{\circ} \mathrm{C}$ at $75 \mathrm{rpm}$. Three milliliters of samples was aliquoted at $0,4,8,16,24,36$, 48,60 , and $72 \mathrm{~h}$ and centrifuged at $2,683 \mathrm{~g}$ at $4^{\circ} \mathrm{C}$ for $15 \mathrm{~min}$.

For the quantitative determination using UV-Vis spectrophotometry, the aliquot was mixed with $1 \% \mathrm{CMC}$ in $0.2 \mathrm{M}$ acetate buffer $\mathrm{pH} 5$ and $1 \%$ DNS in 1:2:3 ratio. Absorbance was read at $520 \mathrm{~nm}$ (maximum wavelength), and the glucose concentration was calculated from the calibration curve. $^{12}$

\section{Optimization of hydrolysis condition}

Optimization of this enzymatic hydrolysis condition was done using the water hyacinth powder which has been delignified as the substrate (a-cellulose) and crude enzyme extract from selected isolate and T. reesei. Two grams of $\alpha$-cellulose from water hyacinth was dissolved in $40 \mathrm{~mL} 0.05 \mathrm{M}$ acetate buffer at $\mathrm{pH}$ optimization and then added $0.4 \mathrm{~mL}$ supernatant of crude enzyme extract. The mixture was incubated at the optimization temperature at $160 \mathrm{rpm}$ for $4 \mathrm{~h}$. Then, $2 \mathrm{~mL}$ of the mixture was aliquoted every $1 \mathrm{~h}$ then mixed with $2 \mathrm{~mL}$ DNS $1 \%$. The mixture was heated for $10 \mathrm{~min}$ and waited until they reach the room temperature. Absorbance was again measured at $520 \mathrm{~nm}$. Optimization was done the conditions given in Table 1.

\section{Separation of $\beta$-glucosidase from crude enzyme extract}

Crude Enzyme Extract was put into the $10 \mathrm{cc}$ syringe then filtered with Whatman membrane filter pore size $45 \mathrm{~mm}$. After that, glucose, a product of $\beta$-glucosidase activity was measured quantitatively using UV-Vis spectrophotometry. Comparison of the volume of cellulose substrate solution: enzyme filtrate: $1 \%$ DNS was 2:1:3. Absorbance was measured at $520 \mathrm{~nm}$.

Table 1: Condition of $\mathrm{pH}$ and temperature optimization.

\begin{tabular}{ccc}
\hline $\begin{array}{c}\mathrm{pH} \\
\text { Temperature }\left({ }^{\circ} \mathrm{C}\right)\end{array}$ & $5-6$ & 7 \\
\hline $28-30$ & Sample 1 & Sample 4 \\
40 & Sample 2 & Sample 5 \\
50 & Sample 3 & Sample 6 \\
\hline
\end{tabular}


Extraction of a-cellulose and preparation of microcrystalline cellulose by enzymatic hydrolysis

Three hundred grams of sifted water hyacinth powder was dissolved in $4 \mathrm{~L} 3.5 \%$ nitric acid containing $40 \mathrm{mg}$ of sodium nitrite and heated for $2 \mathrm{~h}$ in water bath at $90^{\circ} \mathrm{C}$. The filtered residue was washed with distilled water and then dissolved in $3 \mathrm{~L}$ mixture containing $2 \% \mathrm{w} / \mathrm{v}$ each of sodium hydroxide and sodium sulphite. The mixture was heated at $50^{\circ} \mathrm{C}$ for $1 \mathrm{~h}$ and filtered. The residue was first washed with distilled water and then immersed in $2 \mathrm{~L}$ of a bleaching solution containing $3.5 \%$ sodium hypochlorite in distilled water in a 1:1 ratio and boiled for $10 \mathrm{~min}$. The process was followed by filtration and the residue was collected and washed again with distilled water. It was then dissolved in $17.5 \% \mathrm{w} / \mathrm{v} \mathrm{NaOH}$ and heated for $30 \mathrm{~min}$ at $80^{\circ} \mathrm{C}$ and again filtered and washed with distilled water to obtain $\alpha$-cellulose. The $\alpha$-cellulose was cleaned in $2 \mathrm{~L}$ of $1: 1$ water: $3.5 \%$ sodium hypochlorite mixture and heated at $100^{\circ} \mathrm{C}$ for $5 \mathrm{~min}$. It was filtered and washed thoroughly with water and then dried in an oven at $60^{\circ} \mathrm{C} .{ }^{13}$

Ten grams each of $\alpha$-cellulose hyacinths were placed in 3 separate flasks filled with $100 \mathrm{~mL}$ acetate buffer (0.05 M, pH 5). 1, 3, and $5 \mathrm{~mL}$ enzymes from the isolate was added to the three flasks and stirred slowly at $160 \mathrm{rpm}$ $30^{\circ} \mathrm{C}$ for $1 \mathrm{~h}$. Then, the mixture was centrifuged at $10,733 \mathrm{~g}$ at $7-10^{\circ} \mathrm{C}$ for $20 \mathrm{~min}$. The residue was filtered and washed with distilled water to remove residual enzyme before it was dried.

\section{Analysis of crystals by X-Ray ciffraction}

The sample was crushed by porcelain crusher and sieved using 100 mesh sieve to form a fine sample $\pm 50-106 \mu \mathrm{m}$. The sample and the standard (Avicel pH 101) was put on a circular plate mold and diffraction was determined on XRD Bruker D8 Advance ECO diffractometer operated in reflection mode $(40 \mathrm{kV}, 35 \mathrm{~mA})$ using $\mathrm{Cu}-\mathrm{Ka}$ radiation $(\lambda 1=1.54060 \AA$ and $\lambda 2=1.54439 \AA$ ) and employed a step scan mode with initial position $\left({ }^{\circ} 2 \theta\right)$ of $5,0000^{\circ}$, Step Size $\left({ }^{\circ} 2 \theta\right)$ of $0.020^{\circ}$ (76.8 s per step) and ends at $\left({ }^{\circ} 2 \theta\right)$ of 80.009 .

\section{RESULTS AND DISCUSSION}

Isolation cellulose producing fungi from oil palm trunk, rotten logs, and soil

Seven filamentous fungi were isolated from oil palm trunk, rotten logs, and soil. They were (a) isolate 1 , isolate 2 , and isolate 3 , which were isolated from soil; (b) Isolate 4, isolate 5, and isolate 6 which were isolated from rotten logs; and (c) Isolate 7 which was isolated from oil palm trunk. The result of isolated fungi from various sources can be seen in Figure 1-3.

\section{Cellulose production}

Cellulase enzyme was extracted using $80 \quad 0.1 \%$ Tween solutions. The addition of Tween 80 due to its function to increase the permeability of cell walls so that the enzymes could more easily get out of the cell wall. In addition, tween 80 is non-ionic so it does not affect the $\mathrm{pH}$ of the crude enzyme extract. ${ }^{14}$ The extraction process was carried out by centrifugation at $966 \mathrm{~g}$ for $10 \mathrm{~min}$ to separate the extract of the crude enzyme (supernatant) from the mold cells. Centrifugation was carried out at a temperature of $4^{\circ} \mathrm{C}$ to keep the enzyme from breakage.

\section{Screening cellulose activity based on clear zone in CMC media}

Screening of cellulase activity based on the clear zone on CMC media was a semi-quantitative analysis of cellulolytic activity in fungi. The formation of a clear zone proved that the fungi were able to decompose cellulose into glucose in the presence of cellulase enzymes. In this study, the media was contained CMC as cellulose substrate and colored technical agar to clarify the clear zone produced by fungi.

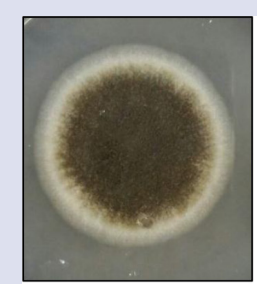

(a)

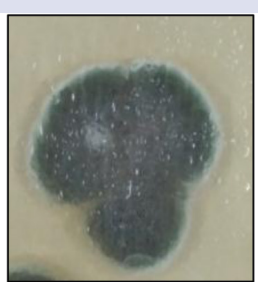

(b)

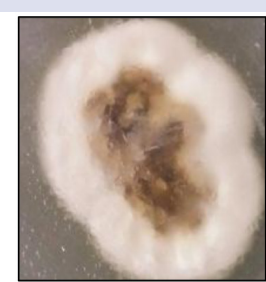

(c)
Figure 1: (a) Isolate 1, (b) Isolate 2, (c) Isolate 3.

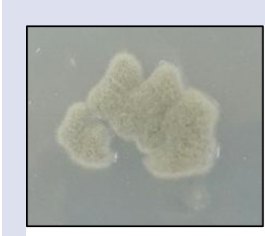

(a)

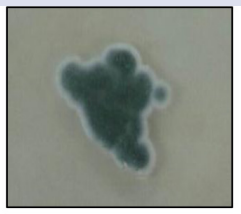

(b)

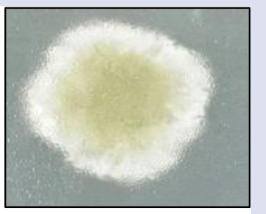

(c)
Figure 2: (a) Isolate 4, (b) Isolate 5, (c) Isolate 6.

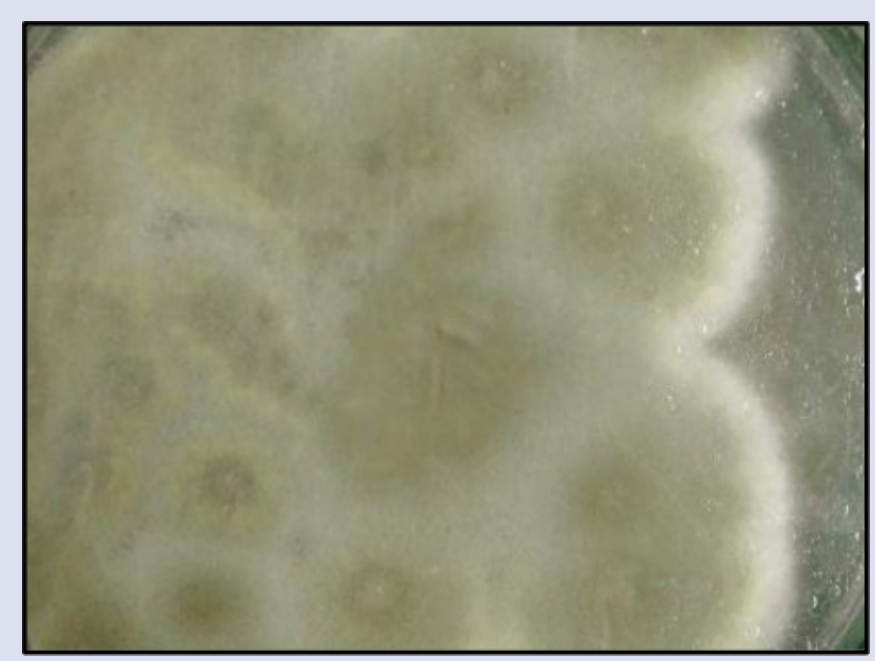

Figure 3: Isolate 7

From the experimental results presented in Table 2 it could be concluded isolates that had cellulolytic activity were isolate 2 , isolate 6 , and Trichoderma reesei as a comparison. The clear zone of isolate 2, isolate 6 , and Trichoderma reesei can be seen in Figure 4-6 respectively. While isolate 1 , isolate 3 , isolate 4 , isolate 5 , and isolate 7 did not show any cellulolytic activity.

The presumptive identity of fungal isolate 2 and 6 was Penicillium chrysogenum and Aspergillus flavus, respectively. The morphological and microscopic observations were explained in Table 3.

\section{Preparation of glucose standard calibration curve}

Standard solution of glucose 1,000 ppm was used as the main solution to make a standard solution of glucose each about $80 \mathrm{ppm}, 90 \mathrm{ppm}, 100 \mathrm{ppm}$, 
Table 2: The result of Screening Cellulase Activity based on The Clear Zone in CMC Media.

\begin{tabular}{ccc}
\hline No & Isolate & Diameter of Clear Zone $(\mathbf{c m})$ \\
\hline 1 & Trichoderma reesei & 5.10 \\
2 & Isolate 1 & 0 \\
3 & Isolate 2 & 2.32 \\
4 & Isolate 3 & 0 \\
5 & Isolate 4 & 0 \\
6 & Isolate 5 & 0 \\
7 & Isolate 6 & 4.4 \\
8 & Isolate 7 & 0 \\
\hline
\end{tabular}

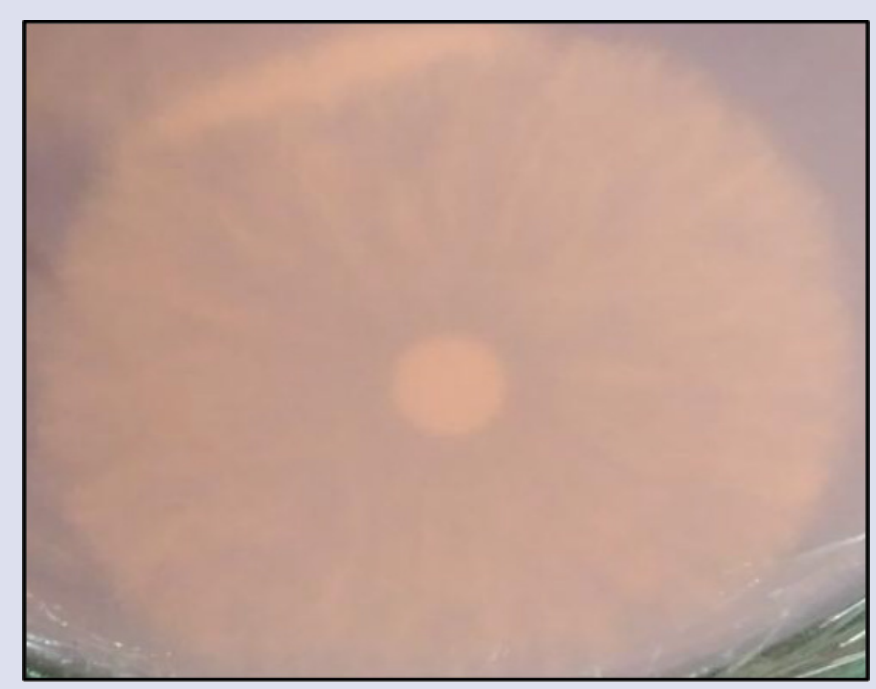

Figure 4: The clear zone of Trichoderma reesei.

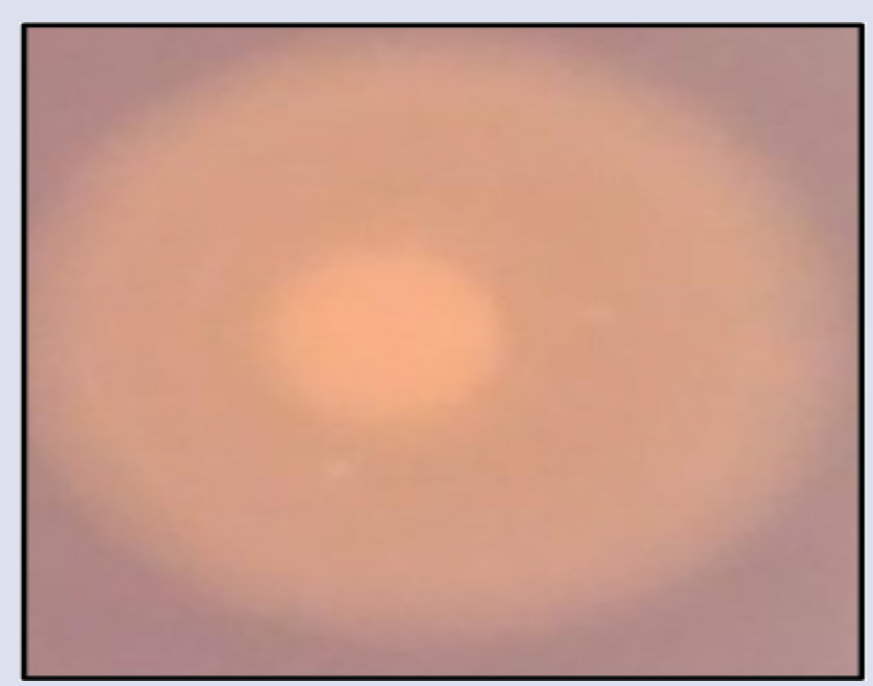

Figure 5: The clear zone of isolate 2.

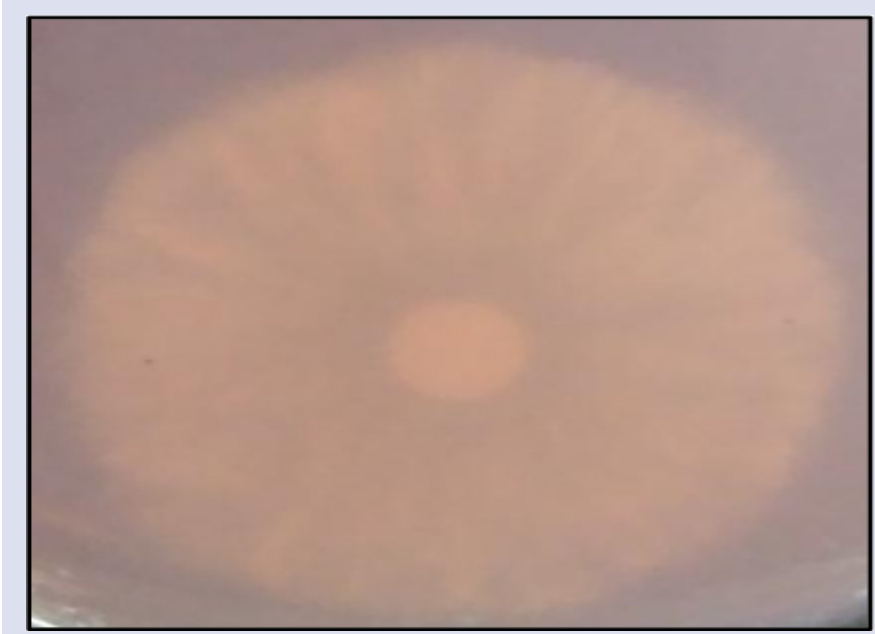

Figure 6: The clear zone of isolate 6.

Table 3: Presumptive identity of fungal isolate 2 and 6.

\begin{tabular}{ccccc}
\hline No & Isolate & $\begin{array}{c}\text { Morphological } \\
\text { Observation }\end{array}$ & $\begin{array}{c}\text { Microscopic } \\
\text { Observation }\end{array}$ & $\begin{array}{c}\text { Probable } \\
\text { Identity }\end{array}$ \\
\hline 1 & Isolate 2 & $\begin{array}{c}\text { Dark green } \\
\text { colored growth }\end{array}$ & $\begin{array}{c}\text { Long chains of } \\
\text { conidia with } \\
\text { smooth, } \\
\text { brush shaped } \\
\text { conidiophores }\end{array}$ & $\begin{array}{c}\text { Penicillium } \\
\text { chrysogenum }\end{array}$ \\
\hline Isolate 6 & $\begin{array}{c}\text { Greenish-yellow } \\
\text { sporulated } \\
\text { Growth }\end{array}$ & $\begin{array}{c}\text { Septate hyphae, } \\
\text { non-septate } \\
\text { conidiophores, } \\
\text { columnar head }\end{array}$ & $\begin{array}{c}\text { Aspergillus } \\
\text { flavus }\end{array}$ \\
\hline & & & \\
\hline
\end{tabular}

110 ppm, 130 ppm, dan 140 ppm. Based on spectrophotometry analysis, linear regression equation obtained was as follow:

$y=0.0095 x-0.545$; with linear regression coefficient $r=0.99904$

\section{Selection of cellulose with sugar reduction method and spectrophotometry}

The results of the screening showed that Trichoderma reesei and isolate 6 were not optimal for this study because of the high glucose concentration produced. This high concentration of glucose indicated that the cellulase activity, especially $\beta$-glucosidase was high because cellulose could be degraded to glucose. Meanwhile, the expected result in this study was low $\beta$-glucosidase activity so that cellulose degradation was low and microcrystalline cellulose could be produced. The isolate 2 was selected as cellulolytic fungi used for enzymatic hydrolysis of a-cellulose from water hyacinth. Data of glucose concentration was shown in Figure 7. Then, isolate 2 was used for further analysis and production of microcrystalline cellulose.

\section{Optimization of hydrolysis condition}

Optimization of enzymatic hydrolysis conditions include of optimization of $\mathrm{pH}$, temperature, and duration. $\mathrm{pH}$ variations compared in this study were $\mathrm{pH} 5$ and $\mathrm{pH}$ 7. Temperature variations tested were $30^{\circ} \mathrm{C}, 40^{\circ} \mathrm{C}$, and $50^{\circ} \mathrm{C}$. In addition, hydrolysis was carried out for $4 \mathrm{~h}$, and every $1 \mathrm{~h}$ the glucose concentration was measured by spectrophotometry using $1 \%$ DNS reagent. Once per $1 \mathrm{~h}$ sampling was aimed to know the optimal time. The substrate used in this enzymatic hydrolysis enzyme optimization 


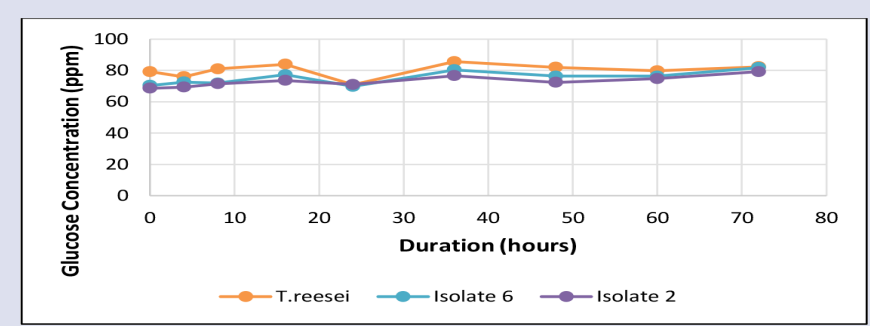

Figure 7: Curve of glucose concentration producing by T. reesei, isolate 2 , and isolate 6 .

Table 4: Comparison of glucose concentration between the enzymes before and the enzyme after filtered.

\begin{tabular}{ccc}
\hline No & Enzyme & Glucose Concentration (ppm) \\
\hline 1 & Before Filtration & 64.0000 \\
2 & After Filtration & 79.2632 \\
\hline
\end{tabular}

stage was $\alpha$-cellulose powder obtained from the delignification of the water hyacinth powder.

Based on Figure 8-10, the lowest glucose concentration was present at the optimization at $30^{\circ} \mathrm{C}$, $\mathrm{pH}$ of solution 5 , and hydrolysis was done for $1 \mathrm{~h}$. Therefore, it was selected as the hydrolysis conditions, because at that condition the glucose produced a low and relatively stable increase in the longer duration.

\section{Separation of $\beta$-glucosidase from crude enzyme extract}

The result of the separation of $\beta$-glucosidase from crude enzyme extract using Whatman membrane filter pore size $45 \mathrm{~mm}$ was shown in Table 4 . There was a decrease in the concentration of glucose between the enzymes before filtered and after filtered. Thus, in the preparation of microcrystalline cellulose using the enzymatic hydrolysis method, the enzyme was filtered with Whatman membrane filter pore size $45 \mathrm{~mm}$.

\section{Preparation of a-cellulose}

The dissolution and heating of water hyacinth powder in the solution of nitric acid added with sodium nitrite was aimed to eliminate lignin in the form of soluble nitro lignin. Subsequently, a lignin liberation of the dregs was made by heating with $2 \% \mathrm{NaOH}$ solution and $2 \% \mathrm{Na}_{2} \mathrm{SO}_{3}$. After that, the lignin residue was removed from the pulp by the addition of sodium hypochlorite and water (1: 1) solution and boiled and the result was Holocellulose. The Holocellulose added with $17.5 \% \mathrm{NaOH}$ solution was useful for the separation between $\alpha$-cellulose, $\beta$-cellulose and $\gamma$-cellulose. $\beta$-cellulose and $\gamma$-cellulose are soluble in $\mathrm{NaOH} 17.5 \%$ while $\alpha$-cellulose is insoluble. Bleaching was done by the addition of $1: 1$ water: $3.5 \%$ sodium hypochlorite mixture and heated at $100^{\circ} \mathrm{C}$. The result of a-cellulose from water hyacinth can be seen in Figure 11 (a).

\section{Preparation of microcrystalline cellulose by enzymatic hydrolysis method}

The preparation of microcrystalline cellulose by enzymatic hydrolysis method was performed by using optimization of extract volume of coarse enzyme added. The variation of extract volume used was $1 \mathrm{~mL}$, $3 \mathrm{~mL}$ and $5 \mathrm{~mL}$ each added to $10 \mathrm{gr}$ of water hyacinth powder which was dissolved in $100 \mathrm{~mL}$ of $0.05 \mathrm{M}$ acetate buffer solution $\mathrm{pH}$ 5. The mixture was then stirred at $160 \mathrm{rpm}$ of temperature $30^{\circ} \mathrm{C}$ for $1 \mathrm{~h}$ to accelerate the homogenization of the solution mixture and hydrolysis by cellulase enzyme. Then, the solution mixture was centrifuged at 10,733 g temperature $70-10^{\circ} \mathrm{C}$ for $20 \mathrm{~min}$ to stop the enzymatic reaction. The residue was

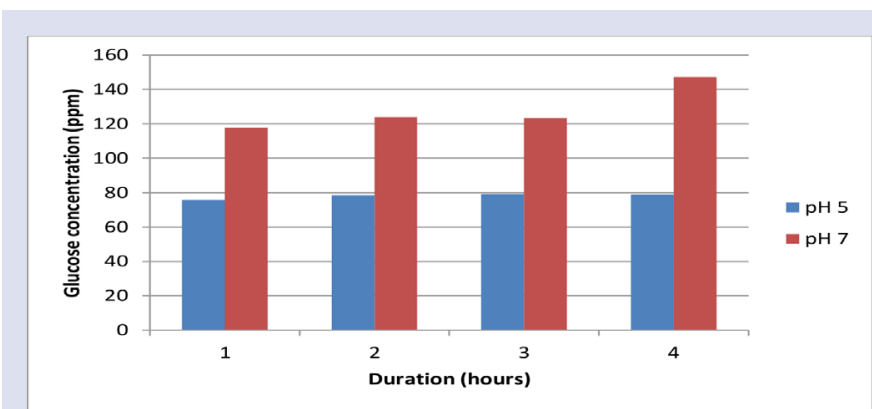

Figure 8: Glucose concentration curve on the optimization of cellulase enzymatic hydrolysis conditions at $30^{\circ} \mathrm{C}$ in solution $\mathrm{pH} 5$ and 7 .

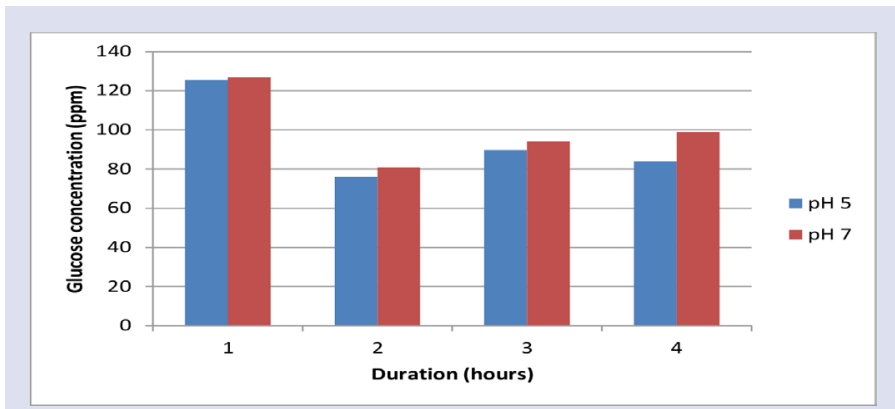

Figure 9: Glucose concentration curve on the optimization of cellulase enzymatic hydrolysis conditions at $40^{\circ} \mathrm{C}$ in solution $\mathrm{pH} 5$ and 7.

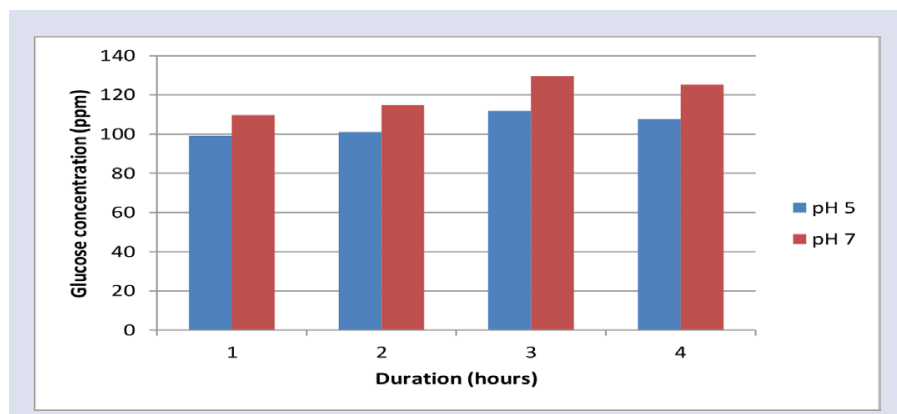

Figure 10: Glucose concentration curve on the optimization of cellulase enzymatic hydrolysis conditions at $50^{\circ} \mathrm{C}$ in solution $\mathrm{pH} 5$ and 7.

then washed, filtered, and rinsed with distilled water to remove residual enzymes. The process was then followed by drying in the oven. The result of microcrystalline cellulose from water hyacinth can be seen in Figure 11 (b).

The supernatant of each hydrolysis process at different volume variations was aliquoted and the glucose concentration was calculated. The results obtained as shown in Figure 12, on volume $5 \mathrm{~mL}(5 \% \mathrm{v} / \mathrm{v})$ extract of the cellulase enzyme extract, the resulting glucose was low. So, the selected volume was $5 \mathrm{~mL}$ for further hydrolysis process. This was in accordance with theory which stated that the higher the concentration of the enzyme would accelerate the reaction. The reaction rate will increase as the enzyme concentration reaches a saturation point when it reaches the saturation point, enzyme concentration is inversely proportional to the reaction rate. ${ }^{15}$ In this study, the possibility of $\beta$-glucosidase activity 


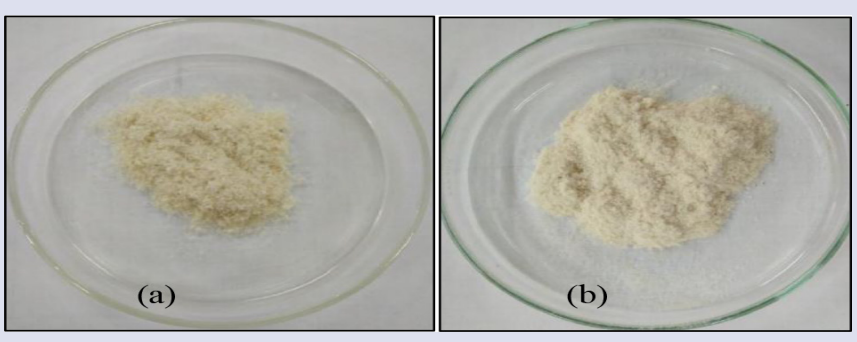

Figure 11: (a) a-cellulose, (b) Microcrystalline cellulose powder from water hyacinth after hydrolysis with cellulase enzyme.

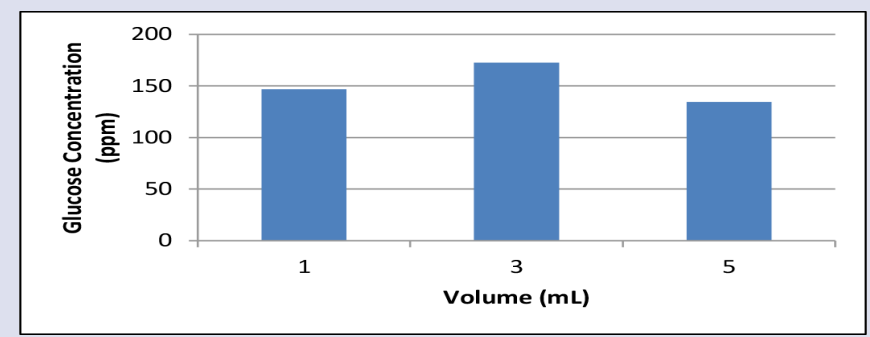

Figure 12: Enzymatic hydrolysis curve by cellulase Enzyme with variation of cellulase enzyme volume.

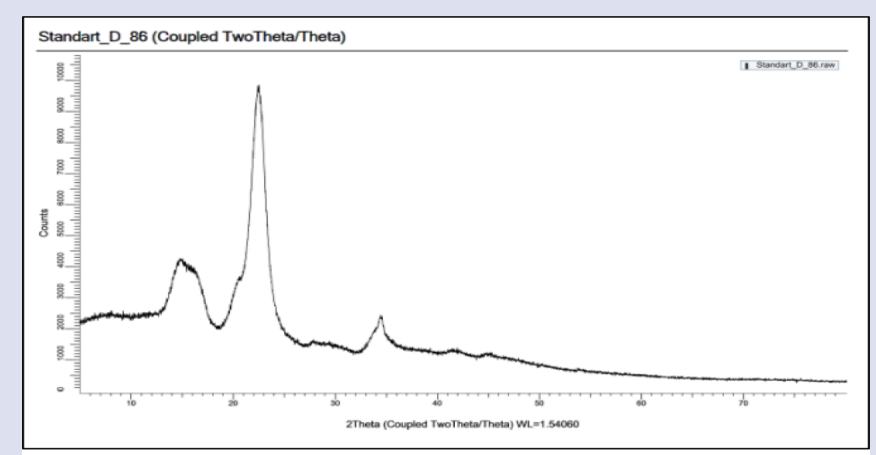

(a)

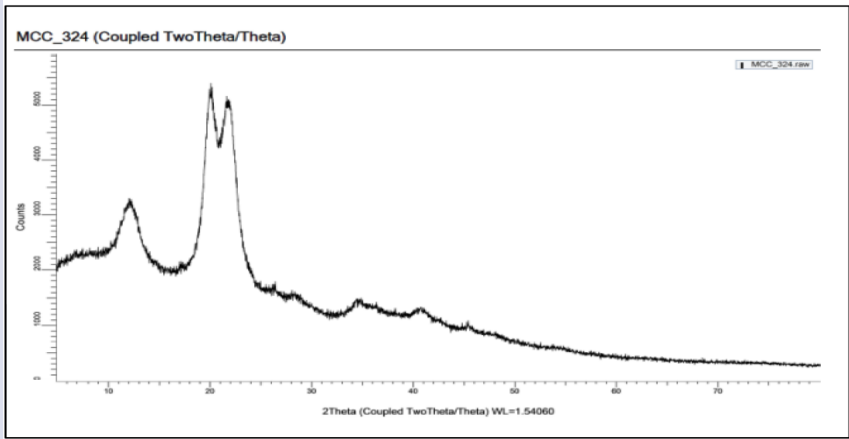

(b)

Figure 13: XRD diffractogram of Avicel pH 101 (a), Hydrolysis Results of Hyacinth powder (b).
Table 5: Comparison of Intensity Values peaks at 2 theta angle between Avicel pH 101 and Sample Hydrolysis of Hyacinth.

\begin{tabular}{cccccc}
\hline & \multicolumn{5}{c}{ Type of MCC } \\
\cline { 2 - 6 } & \multicolumn{3}{c}{ Avicel pH 101 } & \multicolumn{4}{c}{ Hydrolysis result } \\
\hline $2 \theta$ (deg) & 22.5324 & 15.6382 & 20.2002 & 21.8368 & 12.0376 \\
Intensity & 9,851 & 4,086 & 5,323 & 5,104 & 3,304 \\
\hline
\end{tabular}

contained in the cellulase enzyme extract in $5 \mathrm{~mL}$ volume $(5 \% \mathrm{v} / \mathrm{v})$ had passed saturated conditions so that the resulting glucose level decreased.

\section{Analysis of crystal by X-Ray Diffraction (XRD)}

In the Avicel standard pH 101 used (Figure 13 (a)) $2 \theta$ value was 22.5324 . There is a sharp peak showing the crystal with an intensity value of 9,851 and at a $2 \theta$ value of 15.6382 . There is a widened peak showing amorphous properties with values Intensity 4,086 . While in the sample of hydrolysis results (Figure 13 (b)) showed at $2 \theta$ values of 20.2001 and 21.8368 there was a sharp peak showing the crystalline and amorphous properties shown at $2 \theta$ value of 12.0376 . At the peak of microcrystalline cellulose samples the results of hydrolysis with Avicel standard pH 101 have shown a similarity of crystalline properties. The percentage of the standard Avicel pH 101 crystalline index and microcrystalline cellulose samples were $69.6 \%$ and $58.8 \%$, respectively. Comparison of intensity values peaks at $2 \theta$ value between Avicel $\mathrm{pH} 101$ and sample hydrolysis of water hyacinth can be seen in Table 5 .

There is a similarity of the $2 \theta$ crystalline peak value between the sample and cellulose type II. Based on the literature, cellulose type II has a $2 \theta$ crystalline peak value of 20.28 and 21.8 while the amorphous form is shown at $2 \theta$ value of $12.08 .{ }^{16}$ The similarity of diffractogram pattern between microcrystalline cellulose to the type II cellulose is caused by the alkali treatment at the hydrolysis stage. ${ }^{17}$

\section{CONCLUSION}

Isolates of cellulolytic fungi obtained from soil and rotten logs were isolate 2 and isolate 6 respectively. The optimum condition of enzymatic hydrolysis by cellulase enzyme from soil green isolate with the a-cellulose substrate from water hyacinth was at $30^{\circ} \mathrm{C}, \mathrm{pH}$ of solution 5 , in $1 \mathrm{~h}$ and with the concentration of enzyme $5 \%(\mathrm{v} / \mathrm{v})$. Based on the results of XRD analysis, there had been a similarity of crystalline properties of microcrystalline cellulose resulting from hydrolysis with Avicel $\mathrm{pH}$ 101 (as standard). The crystals formed on microcrystalline cellulose of hydrolysis result were type II cellulose crystals.

\section{ACKNOWLEDGEMENT}

The authors acknowledge the financial support from Directorate of Research and Community Engagements of Universitas Indonesia. We also thank Dean of Faculty of Pharmacy, Universitas Indonesia and Head of Laboratory of Microbiology and Biotechnology, Universitas Indonesia for the facilities we used during our study.

\section{CONFLICT OF INTEREST}

The authors declare no conflict of interest.

\section{ABBREVIATION USED}

CMC: Carboxy methyl cellulose; DNS: Dinitro salicylic acid; XRD: $\mathrm{X}$-ray diffraction.

\section{REFERENCES}

1. Abdel-Fattah A, Abdel-Naby M. Pretreatment and enzymic saccharification of water hyacinth cellulose. Carbohydrate Polymers. 2012;87(3):2109-13. 
2. Yan J, Wei Z, Wang Q, He M, Li S, Irbis C. Bioethanol production from sodium hydroxide/hydrogen peroxide-pretreated water hyacinth via simultaneous saccharification and fermentation with a newly isolated thermotolerant Kluyveromyces marxianu strain. Bioresource Technology. 2015;193:103-9.

3. Rezania S, Ponraj M, Din M, Songip A, Sairan F, Chelliapan S. The diverse applications of water hyacinth with main focus on sustainable energy and production for new era: An overview. Renewable and Sustainable Energy Reviews. 2015;41:943-54.

4. Rachmawaty R, Metty M, Slamet P. Sintesis selulosa diasetat dari ecenggondok (Eichhornia crassipes) dan potensinya untuk pembuatan membran. JTeknik Kimia Dan Industri. 2013;2(3):8-16

5. Ohwoavworhua FO, Adelakun TA. Some physical characteristic of microcrystalline celulosa obtained from raw cotton of choclospermum planchonii. Tropical Journal of Pharmaceutical Research. 2005;4(2):501-7.

6. Thoorens G, Krier F, Leclercq B, Carlin B, Evrard B. Microcrystalline cellulose, a direct compression binder in a quality by design environment-A review. International Journal of Pharmaceutics. 2014;473(1-2):64-72.

7. George J, Ramana K, Bawa A, Siddaramaiah. Bacterial cellulose nanocrystals exhibiting high thermal stability and their polymer nanocomposites. International Journal of Biological Macromolecules. 2011;48(1):50-7.

8. Taherzadeh MJ, Karimi K. Acid-based hydrolysis processes for ethanol from lignocellulosic materials: A review. Bioresources. 2007;2(3):472-99.

9. Suryadi H, Sari H, Rosikhoh D. Preparation of Microcrystalline Cellulose from Water Hyacinth Powder by Enzymatic Hydrolysis Using Cellulase of Local Isolate. Journal of Young Pharmacists. 2017;9(1):s19-s23.
10. Teather, Ronald M, Wood PJ. Use of congo red-polysaccharide interactions in enumeration and characterization of cellulolytic bacteria from the bovine. Applied and Environmental Microbiology. 1981;43(4):777-80.

11. Miller G. Use of Dinitrosalicylic Acid Reagent for Determination of Reducing Sugar. Analytical Chemistry. 1959;31(3):426-28.

12. Oktavia Fl, Bambang A, Lutfi M. Hidrolisis enzimatik ampas tebu (bagasse) memanfaatkan enzim selulase dari mikrofungi Trichoderma reseei dan Aspergillus niger sebagai katalisator dengan pretreatment microwave. Journal Keteknikan Pertanian Tropis dan Biosistem. 2014;2(3):256-62.

13. Ohwoavworhua F, Adelakun T, Okhamafe A. Processing pharmaceutical grade microcrystalline cellulose from groundnut husk: Extraction methods and characterization. International Journal of Green Pharmacy. 2009;3(2):97.

14. Szendefy J, Szakacs G, Christopher L. Potential of solid-state fermentation enzymes of Aspergillus oryzae in biobleaching of paper pulp. Enzyme and Microbial Technology. 2006;39(6):1354-60.

15. Lehninger A. Principles of biochemistry. New York: Worth Publishers. 1988;272(2):701-4.

16. Moharram M, Mahmoud O. X-ray diffraction methods in the study of the effect of microwave heating on the transformation of cellulose I into cellulose II during mercerization. Journal of Applied Polymer Science. 2007;105(5):2978-83.

17. Park S, Baker J, Himmel M, Parilla P, Johnson D. Cellulose crystallinity index: measurement techniques and their impact on interpreting cellulase performance. Biotechnology for Biofuels. 2010;3(1):10.

\section{GRAPHICAL ABSTRACT}

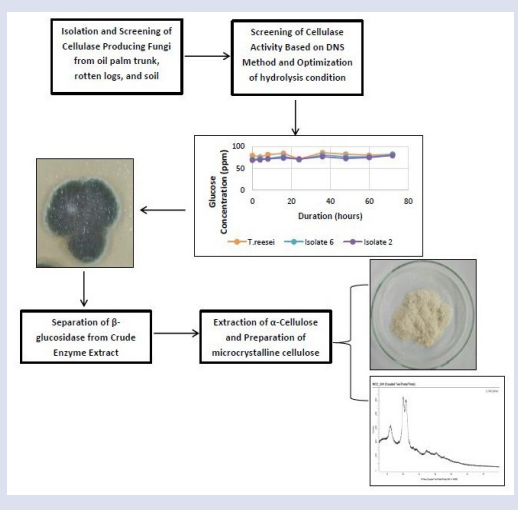

\section{SUMMARY}

- $\alpha$-Cellulose was extracted from water hyacinth

- Cellulase was isolated from fungi which was obtained from soil

- Microcrystalline cellulose was obtained from enzymatic hydrolysis of $\alpha$-cellulose

- The optimal hydrolysis conditions were at $\mathrm{pH} 5,300 \mathrm{C}$, for $1 \mathrm{~h}$ with $5 \% \mathrm{v} / \mathrm{v}$ enzyme

- Based on the pattern of diffraction there was a similarity between microcrystalline cellulose of enzymatic hydrolysis result compared with Avicel pH 101.

Cite this article: Murti MW, Sudarsono MA, Suryadi H. Isolation of Cellulolytic Fungi and Utilization of Its Cellulolytic Activity for Microcrystalline Cellulose Preparation from Water Hyacinth (Eichhornia crassipes). Pharmacog J. 2018;10(6):1082-8. 